\title{
Demand against Law and Using Authority in Corruption Criminal Action
}

\author{
Indra Gunawan Purba ${ }^{1}$, Alvi Syahrin ${ }^{2}$ \\ ${ }^{I}$ Doctoral Program Student of Law Universitas Sumatera Utara, Medan Indonesia \\ ${ }^{2}$ Lecturer in Faculty of Law Universitas Sumatera Utara, Medan Indonesia \\ indrapurba07081978@gmail.com
}

\begin{abstract}
Acts against the law and Abuse of authority in criminal acts of corruption are regulated in Article 2 and Article 3 law No. 311999 as amended to law No. 20 tahun 2001 concerning Eradication of Corruption (UUPTPK). There is a fundamental difference between the two acts, although these two actions are elements that determine whether or not an action can be declared a criminal act, furthermore the two acts are also important to determine whether someone can be blamed for corruption or not. Both actions (against the law and abuse of authority) are important to distinguish the boundaries of corruption and are also interesting to talk about. Especially then if it is associated with the subject of criminal acts of Corruption, namely: Person (naturleijk person) and Corporation (recht person). This means that whether the two acts are against the law and abuse of authority can be done by both legal subjects.
\end{abstract}

Keywords: Legal subjects, people, corporations, criminal acts of corruption, acts against the law, abuse of authority.

\section{Introduction}

Acts against the law and Abuse of authority in criminal acts of corruption are regulated in Article 2 and Article 3 of Law Number 31 of 1999 as amended to Law Number 20 of 2001 concerning Eradication of Corruption (UUPTPK). There is a fundamental difference between the two acts, even though the two acts are elements that determine whether or not an action can be declared a criminal act, furthermore the two acts are also important to determine whether someone can be blamed for corruption or not.

Both actions (against the law and abuse of authority) are important to distinguish the boundaries of corruption and are also interesting to talk about. Especially then if it is associated with the subject of criminal acts of Corruption, namely: Person (naturleijk person) and Corporation (recht person). This means that whether the two acts are against the law and abuse of authority can be done by both legal subjects.

\section{Review of Literature}

\subsection{Corruption Criminal Law Subject}

\section{a. People (naturlijk person).}

The subject of the perpetrators of corruption can be understood from the provisions of Article 1 number 2 of the UUPTPK ${ }^{2}$ and includes those who have the duties, functions and authority as state administrators as stipulated in RI Law Number 28 of $1999^{3}$. Employees, management, directors, commissioners of banks Government, BUMN Bank or BUMD Bank

\footnotetext{
${ }^{1}$ Lecturer in Faculty of Law Al-azhar University, Medan.

${ }^{2}$ Pasal 1 angka 2 UU RI No.31 Tahun 1999 sebagaimana telah direvisi dalam UU RI No.20 Tahun 2001

${ }^{3}$ Pasal 1 angka 1 dan Pasal 2 UU RI Nomor 28 Tahun 1999 Tentang Penyelenggaraan Negara Yang

Bersih Dan Bebas Dari Korupsi, Kolusi, Dan Nepotisme,
} 
are included as people who receive salaries or wages from state or regional finances and also include state administrators.

Everyone means that the subject is suspected of being a corruptor. If you pay attention to the subject of corruption in Article 1 UUPTPK includes every person, civil servant, state administrators, and corporations (legal entities and non-legal entities). The purpose of every person in the UUPTPK is to include anyone, whether his position is a civil servant or a state official, but the element of each person defined in Article 1 number 3 only determines for individuals or corporations.

Mahrus Ali firmly said that the element of everyone in Article 2 paragraph (1) of the UUPTPK includes individuals or corporations, does not include civil servants or officials or state administrators. If a public servant or official or state official is brought before a court for allegedly committing a criminal act of corruption, then Article 2 paragraph (1) of the UUPTPK cannot be used as a basis for indicting a state employee or official or organizer of that state. ${ }^{4}$

The subject of corruption in Article 2 paragraph (1) of the UUPTPK is interpreted to include individuals or corporations in general, other than civil servants or officials. ${ }^{5}$ This is a weakness of the rules written in the law. This provision does not seem to matter even though it is a deep problem. It is unfortunate the facts on the ground that wear Article 2 paragraph (1) of this UUPTPK to civil servants, officials, or state administrators, even though it is not relevant to Article 1 number 3 UUPTPK. Article 1 number 3 UUPTPK should be linked to Article 1 number 2 UUPTPK.

\section{b. Corporations (recht persoon) as Corruption Criminal Law Subjects.}

Perpetrators to be held accountable for criminal acts of corruption are further expanded in scope, namely not only individuals but also corporations. Article 1 point (3) which states that:

"Everyone is an individual or includes a corporation ..."

The formulation of Article 1 paragraph (3), it can be seen that the subject or perpetrators of criminal acts of corruption are individuals or corporations. Also in Article 2 of Law No. 31 of 1999 concerning the eradication of criminal acts of corruption jo. Law No. 20 of 2001 states that:

"In the event that a criminal act of corruption as referred to in paragraph (1) is carried out under certain circumstances, the death penalty may be imposed".

Furthermore, Article 3 states as follows:

"Everyone who aims to benefit himself or someone else, or a corporation, misuses the authority, opportunity or means available to him because of a position or position that can be detrimental to the country's finances or the country's economy, is punished with life imprisonment or the shortest prison sentence. 1 (one) year and a maximum of 20 (twenty) years and or a minimum fine of Rp. 50,000,000.00 (fifty million rupiah) and a maximum of Rp. 1,000,000,000.00 (one billion rupiah). "

\footnotetext{
${ }^{4}$ Mahrus Ali, Hukum Pidana Korupsi, (Yogyakarta: UII Press, 2016), p. 84.

${ }^{5}$ Ibid.
} 
From the aforementioned provisions, it proves the existence of new developments regulated in this Law, namely the regulation of corporations as subject to corruption that can be subject to sanctions.

The formulation of the subject of corruption as regulated in Article 7 can be interpreted that in its understanding includes the corporation as the culprit. The existence of the word "contractor" can be interpreted as a human being or also a corporation, because the work mentioned in the article can be done by humans or by corporations.

Article 20 paragraph (1) and (2) which states that:

Paragraph (1): "In the event that a criminal act of corruption is carried out by or on behalf of a corporation, then criminal charges and conviction can be committed against the corporation and or its management".

Paragraph (2): "A criminal act of corruption is committed by a corporation if the crime is committed by people both on the basis of a work relationship or 51 based on other relationships, acting within the corporate environment both individually and jointly".

Article 5 paragraph (1) states: "Sentenced to imprisonment for a minimum of 1 (one) year and a maximum of 5 (five) years and or a fine of at least Rp. 50,000,000.00 (fifty million rupiah) and a maximum of Rp.250,000,000.00 (two hundred and fifty million rupiah):

1. Giving or promising something to a civil servant or state administrator with the intention that the civil servant or state administrator does or does not do something in his position, which is contrary to his obligations;

2. Giving something to public servants or state administrators because they know that they are related to something that is against obligations, done or not done in their position

Convicted with imprisonment for a minimum of 3 (three) years and a maximum of 15 (fifteen) years and sentenced to a fine of at least Rp.150,000,000.00 (one hundred fifty million rupiah) and a maximum of Rp.750,000,000 (seven hundred fifty million rupiah) for each person who:

1. Giving or promising something to a judge with a view to influencing a case decision submitted to him for trial;

2. Giving or promising something to someone who according to the provisions of the legislation is determined to be an advocate to attend a court session with the intent to influence the advice or opinion to be given in connection with the case submitted to the court for trial.

Article 7 states: (1) Sentenced to a maximum imprisonment of 2 (two) years and a maximum of 7 (seven) years and / or a minimum fine of Rp.100,000,000.00 (one hundred million rupiah) and a maximum of Rp.350,000,000.00 (three hundred fifty million rupiah):

a. Contractors, builders who at the time of building buildings, or sellers of building materials, commit fraudulent actions that can endanger the security of people or goods, or the safety of the state in a state of war;

b. Everyone in charge of overseeing the construction or handover of building materials, intentionally by allowing fraudulent acts. 
c. Every person who when delivering goods needed by the Indonesian National Army and / or the National Police of the Republic of Indonesia commits fraudulent acts that can endanger the safety of the state in a state of war.

d. Everyone who is in charge of overseeing the delivery of items needed by the Indonesian National Army and or the National Police of the Republic of Indonesia intentionally allows fraudulent acts.

Article 13 states: "Any person who gives a gift or promise to a civil servant in view of the power or authority attached to his position or position, or by the gift giver or promise is deemed attached to the position or position, shall be liable to a maximum imprisonment of 3 (three) year and or a maximum fine of Rp.150,000,000.00 (one hundred and fifty million rupiah)."

Article 15 states: "Anyone who commits an attempted, aided, or malicious agreement to commit a criminal act of corruption shall be convicted of the same crime as referred to in Article 2, Article 3, Article 5, up to Article 14."

Article 16 states: "Everyone outside the territory of the Republic of Indonesia who provides assistance, opportunities, facilities, or information for the occurrence of a criminal act of corruption shall be convicted of the same criminal act as a criminal act of corruption as referred to in Article 2, Article 3, Article 5 to with Article 14."

With the regulation of corporations as subject to corruption in Law No. 31 of 1999 Jo. UU no. 20 of 2001 concerning the eradication of criminal acts of corruption, the consequence is that corporations can be held accountable and criminal convictions can be carried out for corruption.

\section{Research method}

Acts against the law and Abuse of authority in criminal acts of corruption are regulated in Article 2 and Article 3 law No. 311999 as amended to law No. 20 tahun 2001 concerning Eradication of Corruption (UUPTPK). Based on this type of study is a normative legal research (Bambang Sunggono, 2012:41). The approach used in this study in the form of concerning Eradication of Corruption (UUPTPK) is to examine all laws or regulations that are related to a legal case that is being addressed.

\section{Discussion}

\subsection{Department against Corruption Criminal Law.}

Corruption criminal acts that require state financial losses are regulated in Article 2 paragraph (1) of the UUPTPK, the formulation of which is as follows:

Any person who unlawfully commits acts of enriching oneself or another person or a corporation that can be detrimental to the country's finances or the country's economy, is sentenced to life imprisonment or imprisonment for a minimum of 4 (four) years and a maximum of 20 (twenty) year and a fine of at least Rp.200,000,000.00 
(two hundred million rupiah) and a maximum of Rp.1,000,000,000.00 (one billion rupiah).

Criminal acts that require state financial losses are also regulated in Article 3 of the UUPTPK, the formulation is as follows:

Any person who has the purpose of benefiting himself or another person or a corporation, misusing the authority, opportunity or means available to him because of a position or position that could be detrimental to the country's finances or the country's economy, is liable to life imprisonment or imprisonment for at least 1 ( one) year and a maximum of 20 (twenty) years and or a fine of at least Rp.50,000,000.00 (fifty million rupiah) and a maximum of Rp.1,000,000,000.00 (one billion rupiah).

The elements of criminal acts (delik) in Article 2 paragraph (1) of the UUPTPK are (1) every person, (2) is against the law, (3) enriches oneself or another person or a corporation, (4) can be detrimental to the country's finances or the country's economy. The elements of criminal acts (delik) in Article 3 of the UUPTPK are (1) everyone, (2) the purpose of benefiting oneself or another person or a corporation, (3) misusing the authority, opportunity or means available to him because of his position or position, (4) can be detrimental to the country's finances or the country's economy. The elements of the criminal act of corruption contained in these articles are:

1. Everyone

2. Against the law

3. Enrich yourself or someone else or a corporation

4. Can be detrimental to the country's finances or the country's economy.

5 . The purpose of benefiting oneself or another person or a corporation.

6. Abusing the authority, opportunity or means available to him because of his position or position.

Against the Law (wederrechtelijk) shows the illegitimate nature of an action (vide: Article 167 paragraph 1, Article 179, Article 180, and Article 190 of the Criminal Code), and the illegitimate nature of an intention (vide: Article 328, Article 339, Article 362, and Article 389 of the Criminal Code). ${ }^{6}$ Against the law is one of the elements of criminal acts in Article 2 paragraph (1) of the UUPTPK, namely the nature of violating specific laws. It is referred to as a special unlawful nature because the word "against the law" is explicitly stated in the offense formula in Article 2 paragraph (1) of the UUPTPK.

The meaning of breaking the law is interpreted by jurists in various meanings. Against the law according to Bemmelen is an act that is contrary to the proper accuracy in the association of people regarding other people or goods, and contrary to the obligations

${ }^{6}$ P.A.F. Lamintang, Dasar-Dasar Hukum Pidana Indonesia, (Bandung: Sinar Baru, 1984), p. 332. 
stipulated in the law. ${ }^{7}$ Against the law according to Hazewink el-Suringa is without its own rights or authority, contrary to the rights of others, and contrary to objective law. ${ }^{8}$

Acts that are categorized as against the law formally are doing something limited to the prohibition of the law. ${ }^{9}$ Whereas what is meant by materially against the law is to do something that is prohibited in the law or based on unwritten legal principles. ${ }^{10}$ If in an article there is actually an element against the law, then the public prosecutor must prove it, if the element is not proven then the verdict is free (vrijspraak). If the element of unlawfulness is not expressly an element of a criminal offense then the unproven element causes the verdict to be free from all lawsuits (onslag van rechtverfolging). ${ }^{11}$

The position of nature against the law in criminal law is very typical. Generally there has been a similar opinion among legal experts in interpreting the nature of violating criminal law. According to Andi Zainal Abidin, the nature of violating the law is one of the essential elements of offense that is stated explicitly or not in an article in the criminal law and it is impossible to convict someone who is not against the law. ${ }^{12}$ According to Roeslan Saleh, convicting someone who is not against the law is meaningless. ${ }^{13}$ A person can be said to have committed a criminal act if the act is illegal.

The element of breaking the law in the UUPTPK is interpreted as being against formal law and against material law. ${ }^{14}$ An act is said to be against formal law if the act is threatened with criminal offense and is formulated as an offense in the law. An act is said to be against formal law if it has matched the prohibition of the law. An act cannot be considered unlawful if the act is not explicitly formulated in the law as a criminal act, even if the act is detrimental to the community. So the standard to determine whether an act is against the law or not is the law.

An action is referred to as a criminal act (strafbaar feit), then the elements or elements that must be present in a criminal act must have behavior and the consequences of the action, things or circumstances that accompany the action, additional conditions which incriminate the criminal, the objective unlawful element, and the subjective unlawful element. ${ }^{15}$ The term illegal act in criminal law is known as the wederrechtelijkheid.

The nature of acts against the law in criminal law formally if an act has matched all the elements contained in the formulation of offense. If there are justifiable reasons, they must also be explicitly stated in the law. Against the law is the same as breaking the law (written law). Attitudes against the law materially in addition to meeting the formal requirements, the

\footnotetext{
${ }^{7}$ J.M. van Bemmelen, Hukum Pidana I: Hukum Pidana Material Bagian Umum, Diterjemahkan oleh Hasan (tanpa tempat: Bina Cipta, 1984), p. 149.

${ }^{8}$ Ibid., p. 150.

${ }^{9}$ Lamintang, Dasar-Dasar Hukum...1984, Op. cit., p. 336.

${ }^{10}$ Moeljatno, Asas-Asas Hukum Pidana, (Jakarta: Rineka Cipta, 2008), p. 141

${ }^{11}$ Mahrus Ali, Op. cit., p. 86.

${ }^{12}$ Ibid.

${ }^{13}$ J.M. van Bemmelen, diterjemahkan oleh Hasnan, Hukum Pidana I, Hukum pidana bagian material Bagian Umum, (Jakarta, Bina Cipta, 1984) p. 102-103.

Penjelasan Pasal 2 ayat (1) UU RI No.20 Tahun 2001 Tentang Pemberantasan Tindak Pidana Korupsi (UUPTPK)

${ }^{15}$ Moeljatno, Asas-Asas Hukum Pidana, (Jakarta: Rineka Cipta, 1993), p. 63.
} 
act must be truly felt by the community as an act that is inappropriate or despicable and has been prohibited by law. ${ }^{16}$

The nature of acts against the law is divided into two, namely against subjective law and against objective law. The nature of going against the subjective law depends on how the mind's inner attitude. While the objective unlawful nature depends on carrying out acts prohibited by law. ${ }^{17}$ So that in criminal law, the meaning of acts against the law is also expanded, in addition to opposing the law (formal), also against the principles of propriety and decency in society (material).

The nature of acts against the law (wederrechtelijkheid) ${ }^{18}$, there are two properties, which are against formal law and are against material laws. The nature of violating formal law is seen from the prohibition of an act by law, then in every offense automatically has the nature of violating the law, while the nature of violating material law is seen from the inner attitude of the perpetrators, then in every offense there is an element of unlawful nature, it must be proven. ${ }^{19}$ It is said as an attitude against material law in addition to meeting formal requirements, materially the act must also be truly felt by the community as inappropriate or despicable and has been prohibited by law. ${ }^{20}$

The element of breaking the law according to $\mathrm{M}$. van Bemmelen can have two meanings namely formal and material, which is categorized as against the law formally by doing something limited to what is prohibited by law. ${ }^{21}$ While against the law materially according to P.A.F. Lamintang is doing something that is prohibited in legislation or based on unwritten legal principles. ${ }^{22}$

If in an article there is actually an element against the law, then the public prosecutor must prove the element, if the element is not proven then the decision is vrijspraak or the verdict is free. Meanwhile, if the element of unlawfulness is not expressly an element of a criminal offense, then the proof of that element does not prove to cause the verdict to be free from all legal claims (onslag van rechtverfolging). ${ }^{23}$

Apart from being against the law, the second element, namely the element of error (schuld). Adagium said, geen straf zonder schuld (no sentence without error), this means that the person convicted must be proven guilty criminal. Error contains two meanings, in the narrow sense which means intentional (dolus/opzet) which means to do with the will and intention or by willing and knowing (willen en wetens), while in the broad sense means dolus and culpa. ${ }^{24}$

Negligence or negligence (culpa) whenever there is a lack of thought in the performer, a lack of knowledge, and a third element, namely the responsibility of the subject. Something

\footnotetext{
${ }^{16}$ EY. Kanter \& SR. Sianturi, Asas-asas Hukum Pidana Di Indonesia Dan Penerapanya, (Jakarta, Storia Jakarta 2002) p. 142

${ }^{17}$ Moeljatno, Asas-Asas Hukum Pidana, (Jakarta: Rineka Cipta, 2009), p. 69.

${ }^{18}$ E.Y. Kanter dan S.R. Sianturi, Op. Cit., p.143-144.

${ }^{19}$ Ibid., p. 147-148.

${ }^{20}$ Ibid., p. 125.

${ }^{21}$ J.M. van Bemmelen, Op. cit, p. 102-103.

${ }^{22}$ P.A.F. Lamintang, Dasar...Op. cit, p. 184.

${ }^{23}$ Ibid., p. 185.

${ }^{24}$ Jan Remmelink, Hukum Pidana, Komentar Atas Pasal-Pasal Terpenting dari Kitab Undang-Undang Hukum Pidana Belanda dan Padanannya Dalam Kitab Undang-Undang Hukum Pidana Indonesia, (Jakarta: Gramedia Pustaka Utama, 2003),p. 173.
} 
can be said as a criminal offense if there is a subject (perpetrator) of the crime itself. So that the perpetrator can be convicted, then in the subject matter there is no criminal offense, both the basis of justification and the basis of forgiveness lack of necessary wisdom. ${ }^{25}$

Delik is also referred to as a criminal offense formulated in the law. The offense can be divided into two based on the way it is formulated, namely formal offense and material offense. In essence, formal offense does not require any consequences, with the occurrence of a criminal offense already stated that the criminal act has occurred and can be convicted. In contrast to material offense, a criminal offense is declared to occur if there is a consequence, which can only be convicted. ${ }^{26}$

Formal offense, namely the actual action carried out even though there is no result, namely state financial losses can be criminalized. The offense of material that is guaranteed is not the elements that must be fulfilled in the provisions of formal law, but rather the actual actions (consequences) can already be convicted. ${ }^{27}$

Article 2 paragraph (1) of the UUPTPK quite clearly determines the concept of state losses in the sense of formal offense in its formulation, "... may be detrimental to the country's finances or the country's economy". The word "can" before the phrase "detrimental to the nation's finances or economy" in the explanation of this article shows that the criminal act of corruption in Article 2 paragraph (1) is a formal offense, namely the existence of a criminal act of corruption is sufficient by fulfilling the elements of the act that have been formulated not by the arising of the consequences. ${ }^{28}$

Apart from the possibility of a state loss, the question which is troubling is whether the state loss must be in a real and definite amount, or can the potential loss of the state's finance (potential loss) be considered as a state loss? This question was raised considering that until now there has not been a common opinion on this matter.

Criminal law experts generally say that the potential for state financial losses can already be categorized as having occurred state financial losses. The word "can" before the phrase "detrimental to the country's finances or the country's economy" indicates that the criminal act of corruption is a formal offense, namely the existence of a criminal act of corruption is sufficient by fulfilling the elements of the act that have been formulated not by the arising of consequences. The loss of the state or the economy of the country need not have happened, but enough with the fulfillment of the elements of the formulated act has been carried out or completed. ${ }^{29}$

MK Decision Number 003 / PUU-IV / 2006 dated July 24, 2006 ruled that the word "can" in Article 2 paragraph (1) of the UUPTPK does not conflict with Article 28 D paragraph (1) of the 1945 Constitution insofar as it is interpreted that the element of state loss must be proven and must be countable. So the issue of the word "can" in Article 2 paragraph (1) of the UUPTPK is more a matter of implementation in practice by law enforcement officials, not concerning the constitutionality of norms. This Constitutional Court Decision states that the explanation of Article 2 paragraph (1) of the UUPTPK is not valid because it is contrary to the 1945 Constitution.

\footnotetext{
${ }^{25}$ SR. Sianturi, Tindak Pidana di KUH Pidana, (Jakarta: Alumni AHM-PTHM, 1983), p. 92.

${ }^{26}$ EY. Kanter \& SR. Sianturi, OP. Cit., p. 237

${ }^{27}$ Ibid., p. 36.

${ }^{28}$ Ibid.

${ }^{29}$ Mahrus Ali, Op. cit., p. 93.
} 
Elucidation of Article 2 paragraph (1) of the UUPTPK which is declared invalid and contradictory to the 1945 Constitution is "Unlawfully meant in this article covers the actions of legal in both the formal and material sense, that is, even though they said acts are not regulated in regulations the law, but if the deed is considered disgraceful because it is not in accordance with a sense of justice or the norms of social life in society, then the act can be criminalized" ${ }^{30}$

The Court is of the opinion that the word "can" before the phrase "detrimental to state finances" there are two relations, namely: (1) obviously detrimental to the state or (2) is likely to cause state losses. This possibility of causing state losses is closer to the intention of qualifying corruption offenses into formal offenses. Between the two relationships there is actually a relationship that is "not yet real", but taking into account the specific and concrete circumstances surrounding the event. ${ }^{31}$

\subsection{Misuse of Authority in Criminal Acts of Corruption.}

The difference between beneficial and enriching lies in the formulation of the previous elements. The beneficial element in Article 3 of the UUPTPK as a result of abuse of authority in the crime, while the enriching element in Article 2 paragraph (1) of the UUPTPK as a result of acts against the law. So for Article 3 of the UUPTPK the element of authority must be fulfilled. While for Article 2 paragraph (1) the element of unlawful fulfillment must be fulfilled, then it can be said that there has been a loss of state finances.

When the element of abuse of authority in Article 3 of the UUPTPK is not proven, by itself the element with the "beneficial purpose ...," does not need to be proven. Likewise, if the element of unlawful acts in Article 2 paragraphs (1) of the UUPTPK is not proven, then the element of "enriching ..." does not need to be proven. Unless Article 2 paragraph (1) of the UUPTPK or Article 3 of the UUPTPK is junto-with Article 55 paragraph (1) of the 01st KUHP, then the defendants have the potential to be convicted of acts of corruption together.

This will certainly have an impact on the next element, namely the element "can harm state finances". If it is still forced to prove the element of "beneficial purpose ...," but the element of abuse of authority is not proven, then it is not right to say that there has been a loss of state finances. If it is still forced to prove the element of "enriching ...", but the element of unlawfulness is not proven, it is also incorrect to say that there has been a loss of state finances, but that it becomes a business loss as a business risk.

Self-benefit means that one does not have to earn a lot of money, but enough to get a small amount of money. Benefiting other people means that other people do not have to get a lot of money, but enough to get a small amount of money. To benefit a corporation means that the corporation does not have to get a lot of money, but enough if it gets a small amount of money.

Abuse of authority is, in principle, an area of state administrative law that cannot be criminalized but is an administrative violation. The element of abusing the authority, opportunity or means available to him because of his position or position can be found in

\footnotetext{
${ }^{30}$ Penjelasan Pasal 2 ayat (1) UUPTPK, menentukan "Yang dimaksud dengan secara melawan hukum dalam Pasal ini mencakup perbuatan melawan hukum dalam arti formil maupun dalam arti materiil, yakni meskipun perbuatan tersebut tidak diatur dalam peraturan perudang-undangan, namun apabila perbuatan tersebut dianggap tercela karena tidak sesuai dengan rasa keadilan atau norma-norma kehidupan sosial dalam masyarakat, maka perbuatan tersebut dapat dipidana."

${ }^{31}$ Ibid.
} 
Article 3 of the UUPTPK. This element is known in the criminal law of corruption, namely the element of "abusing authority, opportunities or means available to him because of his position or position.

What distinguishes the element of abusing authority, opportunity or means available to him because the position or position can be convicted compared to the abuse of authority in administrative law is only an administrative violation. It turns out that if we consider the Post-3 UUPTPK formula, the element of abusing authority, opportunity or means available to it because of position or position does not stand alone, but it has to do with corrupt nature and behavior, namely the existence of an element of purpose to benefit oneself or another person or a corporation.

Everyone who aims to benefit himself or someone else or a corporation, misuse the authority, opportunity or means available to him because of his position or position that can harm the country's finances or the country's economy, is criminally charged ... " ${ }^{32}$

Based on the formulation in Article 3 of the Company Law, the formulation can be considered before the element of "abusing authority, opportunity or means available to him because of his position or position", namely the element of "the purpose of benefiting oneself or another person or a corporation", both of these formulations must be mutually related to each other. So it is not certain that the element of "abusing the authority, opportunity or means available to him because of his position or position" can be imposed by the criminal if previously the element of "the purpose of benefiting oneself or another person or a corporation" is not proven.

The element of the act of "abusing the authority, opportunity or means available to him because of his position or position" in the context of criminal law is to use the authority or power, opportunity, or means attached to the position or position that is being held or occupied by the perpetrators of criminal acts of corruption for purposes other than from the purpose of granting such authority or power, opportunity or means. ${ }^{33}$

The element "against the law" in Article 2 paragraph (1) of the UUPTPK as the best and delict, the element of "abusing authority in Article 3 of the UUPTPK also as the best and delict. If the element of abuse of authority is not proven, then against civil servants or state officials suspected of committing criminal acts of corruption cannot be categorized as abusing authority.

Based on autonomous theory, criminal law has the autonomy to provide a different understanding from the understanding contained in other branches of law. In this context if the notion of "abusing authority" is not found explicitly in criminal law, then criminal law can use the same meaning and words in other branches of science. ${ }^{34}$

If the criminal law does not provide an understanding of the abuse of authority, and that understanding is only found in the jurisdiction of the state administration, then the understanding automatically refers to the understanding in the state administrative law. Understanding the abuse of authority in the context of state administrative law in three forms: ${ }^{35}$

\footnotetext{
${ }^{32}$ Pasal 3 UUPTPK

${ }^{33}$ Ermansjah Djaja, Tipologi Tindak Pidana...Op. cit., p. 159.

${ }^{34}$ Ibid., p. 427.

${ }^{35}$ Ibid., p. 427-428.
} 
a. Abuse of authority to carry out actions that are contrary to the public interest or to benefit personal, group or group interests.

b. Abuse of authority in the sense that the official's actions are intended in the public interest, but deviates from the purpose of the authority granted by written law or regulations.

c. Abuse of authority in the sense of abusing procedures that should be used to achieve certain goals, but has used other procedures to carry out.

The element of "abusing the authority, opportunity or means available to him because of his position or position" in Article 3 of the UUPTPK must be addressed as an official or an official in the government. So that the element of "abuse of authority, opportunity or means available to him because of his position or position" is held or occupied by the perpetrators of corruption for other purposes than the purpose of granting such authority, opportunity, or means. ${ }^{36}$

Means are equipment or facilities, misusing facilities is abusing existing facilities or equipment attached to the perpetrators because of their position or position. The element of abusing authority, opportunity or means available to him because of his position shows that between authority, opportunity, means, and position or position is an integrated unit owned by officials (civil servants) who commit acts of corruption. Because by giving a position or position to an administrative official, the authority, opportunity, or means automatically follow. ${ }^{37}$

Based on the description, abusing authority, opportunity or means is only related to the position or position attached to a civil servant who commits a criminal act of corruption. Apart from civil servants or officials including BUMN and BUMD employees, they cannot be constructed as an abuse of authority. If the defendant is charged with Article 3 of the UUPTPK but not as a civil servant, then in this case the legal construction has been wrong in understanding the essence of abuse of authority and is against the law. ${ }^{38}$

\section{Conclusion}

There are 2 legal subjects in a criminal act of corruption, namely: (1) a person, that is, everyone means that the subject is a suspect of corruption. If you pay attention to the subject of corruption in Article 1 UUPTPK includes every person, civil servant, state administrators, and corporations (legal entities and non-legal entities). The purpose of every person in the UUPTPK is to include anyone, whether his position is a civil servant or a state official, but the element of each person defined in Article 1 number 3 only determines for individuals or corporations. (2) Corporations as Actors and those who can be held liable for criminal acts of corruption committed by their management.

Against the law (wederrechtelijk) shows. The meaning of breaking the law is interpreted by legal experts. Bemmelen stated that fighting the law is an act that is contrary to the proper accuracy in the association of people regarding other people or goods, and is contrary to the obligations stipulated in the law. Hazewink el-Suringa stated that against the

\footnotetext{
${ }^{36}$ R. Wiyono, Pembahasan Undang-Undang Pemberantasan Tindak Pidana Korupsi, (Jakarta: Sinar Grafika, 2009), p. 38

${ }^{37}$ Ibid., p. 102.

${ }^{38}$ Ibid.
} 
law is: without the rights or authority itself, contrary to the rights of others, and contrary to objective law. Van Hattum states must be limited only to written law or contrary to written law. According to Simons as long as it is mentioned in the law. Against the law according to Vos is an act that is not allowed by the community. Against the law according to Enschede also includes fighting the norms of society. Acts that are categorized as against the law formally are doing something limited to the prohibition of the law. Whereas what is meant by materially against the law is to do something that is prohibited in the law or based on unwritten legal principles. If in an article there is actually an element against the law, then the public prosecutor must prove it, if the element is not proven then the verdict is free (vrijspraak). If the element of unlawfulness is not expressly an element of a criminal offense then the unproven element causes the verdict to be free from all lawsuits (onslag van rechtverfolging)

Abusing means that in the context of criminal law the existence of rights or powers that are not carried out properly as it has benefited others, children, grandchildren, family, or cronies. Abuse of authority is, in principle, an area of state administrative law that cannot be criminalized but is an administrative violation. The element of abusing the authority, opportunity or means available to him because of his position or position can be found in Article 3 of the UUPTPK. This element is known in the criminal law of corruption, namely the element of "abusing authority, opportunities or means available to him because of his position or position. What distinguishes the element of abusing authority, opportunity or means available to him because the position or position can be convicted compared with the abuse of authority in administrative law is only an administrative violation. It turns out that if we consider the Post-3 UUPTPK formula, the element of abusing authority, opportunity or means available to it because of position or position does not stand alone, but it has to do with corrupt nature and behavior, namely the existence of an element of purpose to benefit oneself or another person or a corporation.

\section{References}

Abidin, A. Zainal, (2007). Hukum Pidana I, (Jakarta: Sinar Grafika)

Ali, Mahrus (2016).Hukum Pidana Korupsi, (Yogyakarta: UII Press)

Bemmelen, J.M. van, (1984). Hukum Pidana I: Hukum Pidana Material Bagian Umum, Diterjemahkan oleh Hasan (tanpa tempat: Bina Cipta)

Chazawi, Adami. (2005) Hukum Pidana Materil dan Formil Korupsi di Indonesia, (Malang: Bayumedia Publishing).

Hamzah, Andi. (2004)Pemberantasan Korupsi Melalui Hukum Pidana Nasional dan Internasional, (Jakarta: RajaGrafindo Persada).

Huda, Chairul. (2006) Dari Tiada Pidana Tanpa Kesalahan Menuju Tiada Pertanggungjawaban Pidana Tanpa Kesalahan, (Jakarta: Kencana).

Kanter, EY. \& SR. Sianturi. (2002) Asas-asas Hukum Pidana Di Indonesia Dan Penerapanya, (Jakarta, Storia Jakarta).

Lamintang, P.A.F. (1984) Dasar-Dasar Hukum Pidana Indonesia, (Bandung: Sinar Baru).

Moeljatno. (2008) Asas-Asas Hukum Pidana, (Jakarta: Rineka Cipta)

Moeljatno. (1993) Asas-Asas Hukum Pidana, (Jakarta: Rineka Cipta).

Moeljatno, (2009)Asas-Asas Hukum Pidana, (Jakarta: Rineka Cipta). 
Minarmo Nur Basuki. (2009) Penyalahgunaan Wewenang dan Tindak Pidana Korupsi Dalam Pengelolaan Keuangan Daerah, (Yogyakarta: Leksbang Mediatama).

Rajagukguk, Erman. (2006) "Pengertian Keuangan Negara dan Kerugian Negara", Makalah yang Disampaikan pada Seminar Pengertian, Keuangan Negara Dalam Tindak Pidana Korupsi, Jakarta.

Remmelink, Jan. (2003) Hukum Pidana, Komentar Atas Pasal-Pasal Terpenting dari Kitab Undang-Undang Hukum Pidana Belanda dan Padanannya Dalam Kitab UndangUndang Hukum Pidana Indonesia, (Jakarta: Gramedia Pustaka Utama)

Soleh, Roeslan. (1987) Sifat Melawan Hukum Dari Perbuatan Pidana, (Jakarta: Aksara Baru)

Sianturi, SR. (1983) Tindak Pidana di KUH Pidana, (Jakarta: Alumni AHM-PTHM)

Tongat. (2008) Dasar-Dasar Hukum Pidana Indonesia Dalam Perspektif Pembaharuan, (Malang: UMM Press),

Prints, Darwin (2002). Pemberantasan Tindak Pidana Korupsi, (Bandung: Citra Adtya Bakti).

Wiyono, R. (2009) Pembahasan Undang-Undang Pemberantasan Tindak Pidana Korupsi, (Jakarta: Sinar Grafika). 